\title{
Flexible Architecture: Optimization of Technology and Creativity
}

\author{
Dr. Mohd. Anas ${ }^{\# 1}$, Safiullah ${ }^{* 2}$, Zeba Nisar ${ }^{* 3}$ \\ \# Department of Mechanical Engineering, Integral University, Lucknow, India \\ 1 anas@iul.ac.in \\ * Department of Architecture and Planning, Integral University, Lucknow, India \\ 2safi@iul.ac.in, ${ }^{3}$ zeba@iul.ac.in
}

\begin{abstract}
Natural beauty goes beyond standards and cliches which needs to be stored for future generations to enjoy it in its best form. The quest for sustainability in context of nature and environment directs anthropoid to adapt the new conspicuous ideology of 'Flexible Architecture' that believes in responding to change rather than staying idle. The Flexible Buildings is a new genre of Architecture which believes in full utilization of existing resources, willingness to embrace changes and challenges by profound utilization of new technology aided by the computer technology support. The unconventional Flexible architecture is capable of defying worldly and environmental challenges such as melting of ice, rise in sea level, migration of refugee, global warming, dense population in cities, disastrous events etc, while aesthetic consideration is also given due importance parallely.

Flexibility in architecture was introduced by Walter Gropius in 1950s which has progressed to a more advance level in few decades. A lot of research has been conducted in this field, which largely describes contemporary flexible architecture as designed for multipurpose utilization. Global consumerism, availability of materials and new technology adopted play a vital role in its world wide acceptance. The advanced techniques adopted in the design of buildings, structures, products, gave the opportunity to the interior space elements like ceiling, furniture, windows, doors, etc., not to be rigid, thus allowing for more flexibility space wise, setting wise, beauty wise etc. The different needs and requirements of people, community and country are analyzed which lead to the significant achievement of flexible design and architecture. This paper uniquely analyzes how the flexible architecture comes out to be a solution for prevailing problems in different countries.
\end{abstract}

Keyword-Flexible, Architecture, Adaptive reuse, Tent Structure, Low Cost, Sustainable

\section{INTRODUCTION}

The noblest architecture can sometimes do less for us than a siesta or an aspirin... Even if we could spend the rest of our lives in the Villa Rotunda or the Glass House, we could still often be in a bad mood: Alain de Botton, The Architecture of Happiness

Architecture is all about creating spaces that triggers emotions and creates a sense of place which may be coined as 'a friendly way of living with nature'. The neural satisfaction for being inhibited to a system and an urge to occupy it lifelong is the outcome of a real great architect. The prevailing aspects of the relationships provided by architecture that stands or exists today are of modern urban, rural and flexibility. Besides, global consumerism and mobility the other factors that have transformed architecture to movable, adaptable, transformable modes are the availability of steels and weldable materials, easily mountable riveted structures, screwable members etc. which help to stabilize system by use of optimized energy and resources from nature. Contemporary architects with their unconventional architecture are trying to adopt the existing system.

Flexible building is a differential coefficient of various parameters of architecture and society that has come forth to serve different needs and requirements of people, community and country. The appealing and flexible technology in architecture seems to be quite importunate to modern architects and designers. As this conspicuous ideology believes in to revolutionize rather than status qua, thereby creating flexible, stimulating and livable environment. Flexible design and architecture comprises a thought in a vicinity design grasps one's notion and imagination to expand as directed by a range of purposes and utilization. Flexible architecture has inspired designers around the world with its singular characteristics of lightness, transience and practicality, the possibilities of portability, prefabrication, demount-ability, dynamism, adaptability, mobility of structures which is ever-growing. 
The challenges that the world faces today are melting of ice, rise in sea level, migration of refugee, global warming, and dense population in cities, disastrous or unpredicted events, and at the same aesthetics consideration to enjoy the beauty of nature and store it. Economically and technologically, the world is dominated by some featured developed countries and the multinationals. As per statistics of 2002, two billion people in the world live below the poverty limit and eight hundred people suffered from starvation illuminating the fact that massive poverty do still exists irrespective of rapid worldwide development . Rapid urbanization and globalism, has revived and boosted humans' desire to improvise their living conditions. On the other hand, unheralded natural calamities such as earthquake, floods, epidemic etc. are still expected and pose a threat to human existence which can .be answered by adopting the unconventional Flexible architecture, capable of defying worldly and environmental challenges.

\section{FleXible ARCHITECTURE: Methodology AdOPTED IN DIFFERENT COUNTRIES}

Since time immemorial, every living species that existed on earth build their own habitat capable of catering their intrinsic needs. Merely, humans' species is the privileged one which believed perpetually in evolving new ideas for making their dwellings thereby accepting the philosophy 'change is the new constant' which gave way to Flexibility in Architecture which have adaptability, mobility, transform-ability and inter-activeness as its attributes. The world is rapidly developing building technologies and new building materials, capable of bringing revolutionary changes into the architectural world and allowing towards more fantastic imagination and unique results. What was unthinkable before has taken a new shape in front of us, indicating a different way of thinking about ways of living. Various examples of countries with advanced innovation of flexible architecture are presented below.

\section{1) Japan- Architecture with Innovation and Nationalism}

'This unstable environment has created a culture that accepts cycles of destruction and renewal as a part of natural life': Sarah Ichioka, Japanese- American Urbanist. In Japan, social liberalism corroborated by belief of improving living and working conditions of the nation sought out to find architectural design free from unnecessary ornaments making the country as hotbed for contemporary architecture with lots of conspicuous edifices. Being earthquake prone and the disaster struck area after World War- I, it paved ways for 'scrap and build design culture' capable of retrieving it from catastrophic attack by accepting it as a natural part of life, thereby adding a new dimension to architecture of this country.

The first Japanese architecture movement Metabolist in 1960, after the World War II, achieved synthesis and harmony of tradition, engineering, human and nature of which Nakagin tower of Tokyo is the best example. Metabolic design is based on exchange-ability, modular buildings, prefabricated parts and capsules which represents organic growth and restructuring within buildings promoting recyclability of components. The Nakagin tower whole design is a prototype of sustainable architecture which can be dismantled and rearranged in minimum time. All capsules are prefabricated and each module is plugged in to the central core and can be replaced or exchanged if necessary.

After 1990s, architects were more interested in the new technology driven by computer application for optimized use of spaces. The technology needs to be exploded to generate the architecture which could be more flexible to suit assorted occupants in various situations. Other example is City in the air designed by Arata Isozaki who was dissatisfied by chaos of Tokyo and proposed a city raised on mega columns from which emerged branches and the whole city was raised from the ground to sustain land covers. Likewise, Floating city by Kiyonari Kikutake is a housing project erected in a lake. It was designed to accommodate large populace within flexible and extensible structures in the form of identical spirals units supporting organic growth. 

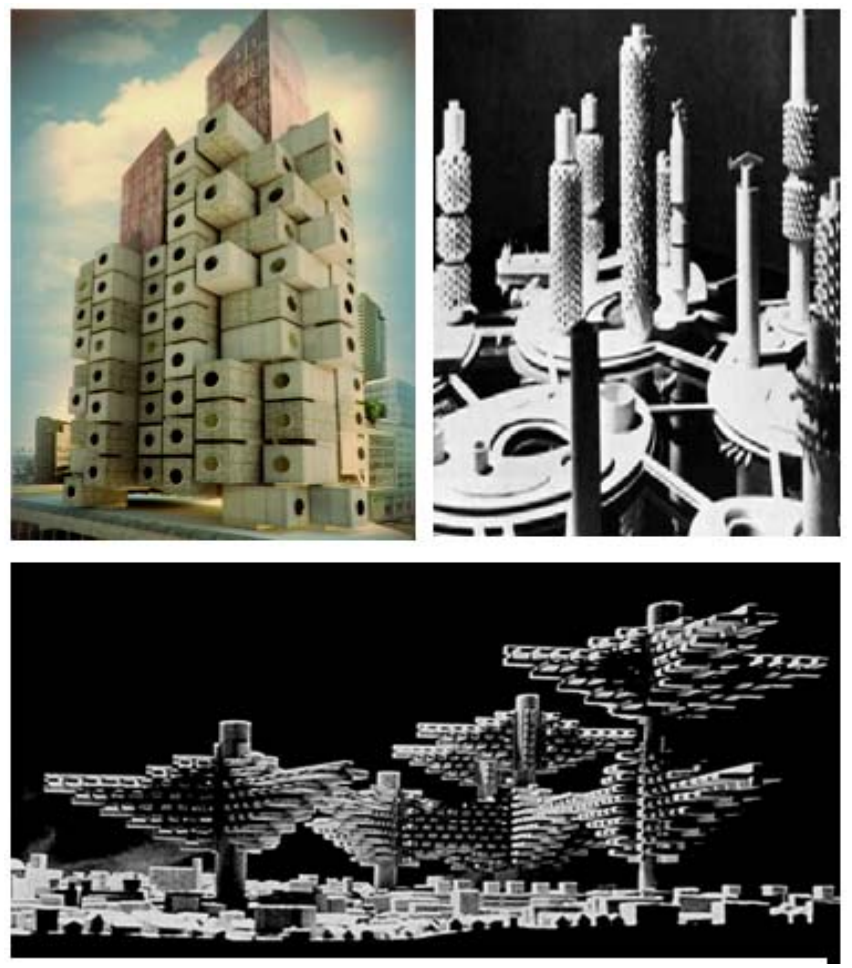

Fig. 1. (top left) Nakagin tower, Tokyo, (top right) City in the Air, (bottom) Floating city

\section{2) Berlin, Germany- Architecture of transportable minimal housing unit}

Post war Berlin adopted 'Minimalist Approach' targeted to create adaptable spaces which can be used for multipurpose activities without imposing any financial burden and also fulfil the requirements of contemporary designers to make flexible buildings encouraging flexible performances. The city theatre of Berlin is for musical and demonstrative programs. A little change in middle stage of the theatre rotates it by 180 degree, without any extra construction.

The Loft cube, as the name suggests is a dwelling entity designed by a German architect Werner Aisslinger in 2003 which intended to create a temporary and minimal housing unit for a particular group of people- 'the modern urban nomads' who occupies a space for limited period of time. The idea was to house these loft cubes on the existing roof of an urban structure in mega polis, contributing additive living space in already over populated areas. Utilization of unused space provided a realistic

solution to meet the legitimate problem of housing shortage in large cities. Two types of modules were proposed for these modular portable dwelling units which were well suited for individual or couple occupancy:

- Square plan measuring $6.25 \mathrm{~m}$ each side

- Rectangular plan measuring $8.75 \mathrm{~m}$ X 6.25m

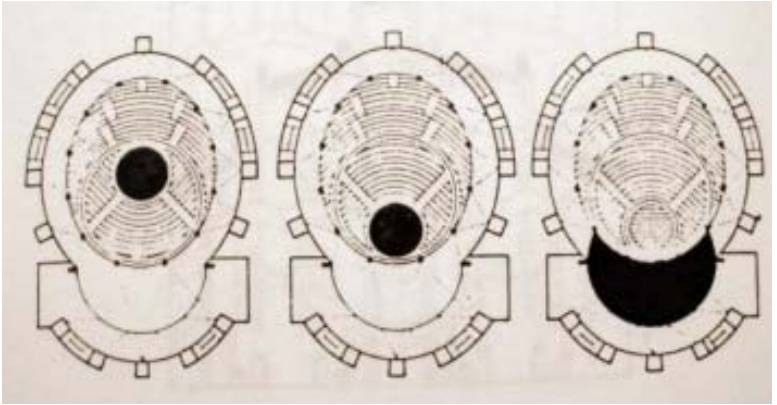

Fig. 2. The city theatre of Berlin wherein the stage rotate 180 degree 

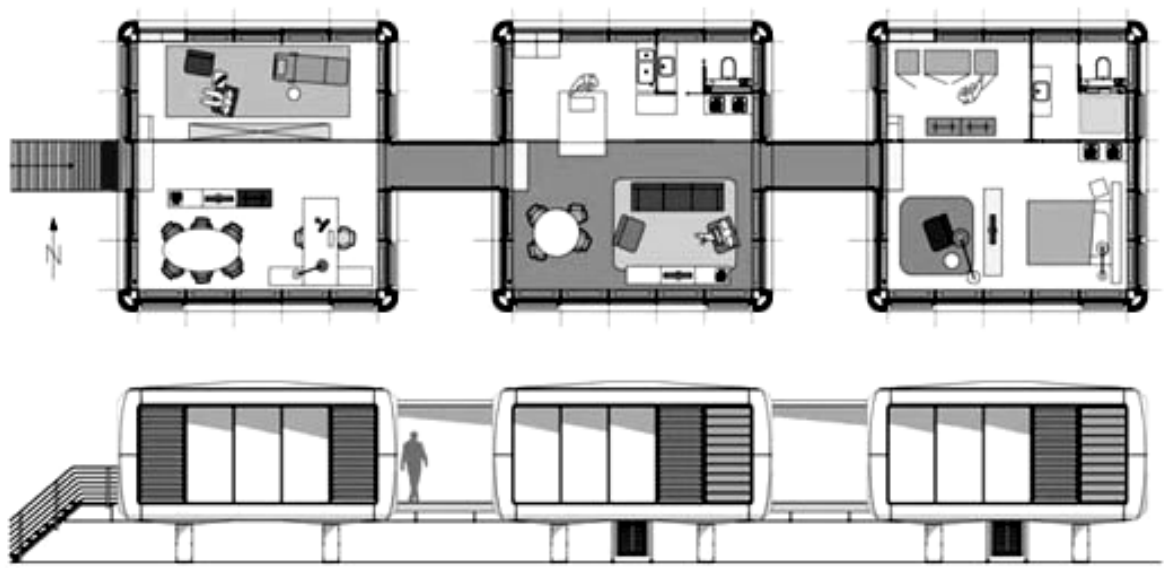

Fig. 3. Loft cube: Plan and Elevation

\section{3) Hong Kong, China- World's Largest Car Parking System}

Hong Kong continues to be the World's densest urban area in context of high income and population which makes it a surviving role exemplar of compact development and transit dependence. Due to rapid urbanization and large population assimilation, car parking systems at important sites faces biggest challenge now. Reported by Financial Times, it has become world's most expensive parking place which costs $\$ 620,000$ per space of a car. According to latest Parking Rate Survey by Colliers Internationals, this city has the most exorbitant monthly parking fees in the Asia-Pacific. Therefore, car parking management is of prime concern in such a transit oriented city with large populace. Further, it has been observed that these limited costly allotted car park spaces were either occupied or left vacant at different times in a day showcasing inefficient management system needful of contiguous modification. . The limited space of the city demanded high utilization rate of architectural space for better city life by eliminating traffic congestion due to illegal parking and reduction in pollution levels also. The solution to these problems evolved in form of automated car park management systems or 3-dimensional car parking systems that employs computer programmes and some basic electronic components such as sensors, relays, limit switches and DC motors for efficiently parking cars in a given space and managing them according to desired parking duration.

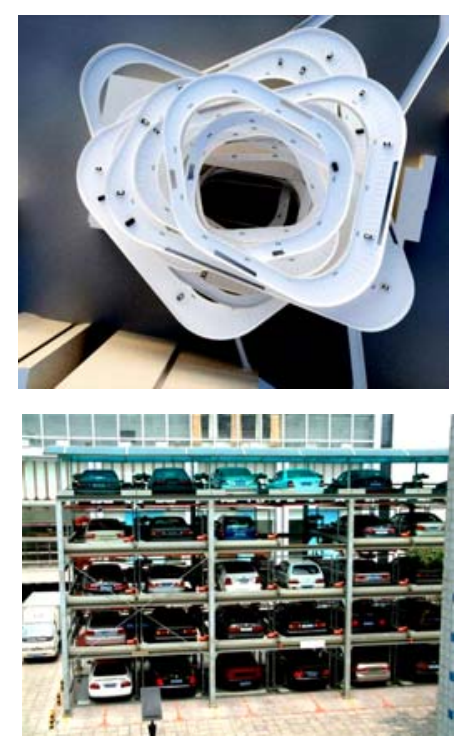

Fig. 4. Multilevel car parking Systems 


\section{4) Dubai, UAE - Home of Architectural Wonders}

Dubai is considered as the country of architectural wonders which was beyond the rigid concepts of traditional style to more dynamic one corresponding to environment and also capable of creating landmarks to be cherished by succeeding generations. Dynamic movement in architecture marks a new era with the concept of buildings in motion of which Dynamic Tower Hotel at Dubai designed by Architect David Fisher (2008) is an example. The design work of this 1375 feet tower housing 80 stories commensurate in 2008 and it is projected to be physically built by 2020. The tower has a fixed central core to which apartments are connected which will be able to enjoy 3600 degree view due to rotation which is governed by climatic and vision factors. The building will be self powered by means of solar panels and wind turbines making it a 'Green Power station'. Further, it will incorporate prefabrication technology whereby individual units will be build off site including services, and on-site it will be attached to the central core. Due to its motion the face of the building will keep on changing emphasizing on dynamism theory.

It is estimated that by the year 2050, the world population will inflate to 9 billion, for which more infrastructure will be required to cater and accommodate them keeping in mind the need of employment opportunities and liveable conditions. Floating architecture is an egregious solution to deal with major problems facing the world such as rising sea levels, rapid urbanization and population over spill. Dubai is famously known for its two biggest sea reclamation projects- two artificial islands, one formed in the shape of a huge palm tree (Palm Islands) and the other as the map of the world (World Island, Dubai) so as to extend coastline of Dubai to make it perfect for tourist attractions. Sand from the Persian Gulf was used to build them. These served as extensions to the main land which could accommodate three times more tourists than before and will aid in more revenue generation. These islands are designed to house waterfront apartments, residential villas, water homes, and hotels along with marinas, health spas, shopping malls, restaurants, cinemas, sports facilities and diva sites, the stylish architecture of these areas became the icon of wealth and luxury. With Burj Khalifa and Palm City (largest artificial island) Dubai has become home of architectural wonders as declared by the worlds press.

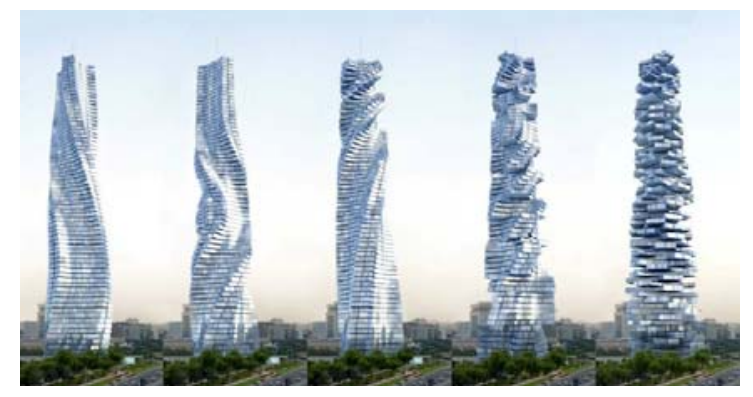

Fig. 5. Dynamic Tower (proposed), building in motion, Dubai, UAE

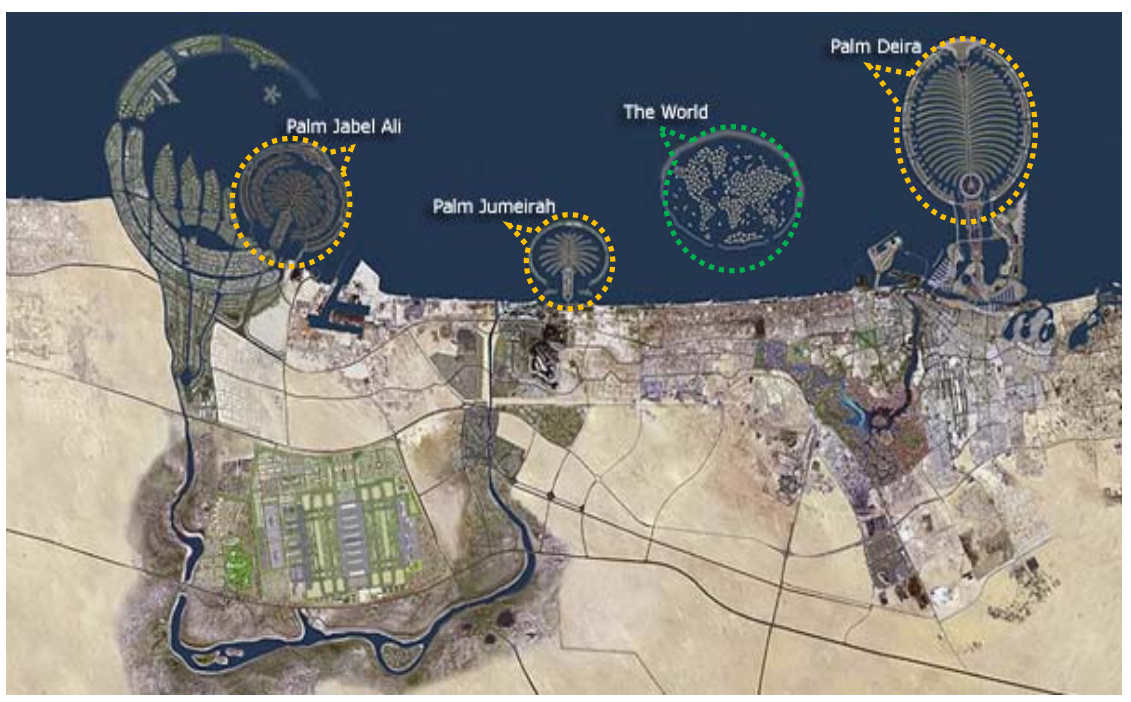

Fig. 6. Artificial Islands, Dubai, UAE 


\section{5) Kashmir (India) - Heaven on Earth}

Randolph Langenbach an US based architect visited Kashmir (1984) and his studies are a rich resource of information on the traditional architecture of Kashmir. After analysing the behaviour of traditional building components, he advises its preservation and adaptation for better living and sustenance of life. According to expert's viewpoint, the traditional architecture of Kashmir, both Taq- solid bearing wall with timber lacing and Dhajji-Dewari- brick nogged timber frame construction is manifestation of architectural systems optimized over a period of time in context of climate, soil and threat from natural disasters as the area lies in Seismic Zone-V. The system incorporated the use of wood as structural element of house with bricks raised in mud mortar, which effectively survive earthquakes because of the flexibility rather than strength. During winters the region witnesses the harshest spell of winter, the 40-day cold spell of winter, locally called Chillai Kalan which demands architecture to create comfortable and flexible spaces that does not impact human life but is sustainable and supportive.

Floating architecture with most of wooden work could help to deal with major problems on hills in Kashmir, where tourism is the main source of earning for common man. Rowing in thin-long boats with artistic arches and roofing and staying in the boat houses of Dal-Lake, Srinagar (one of the biggest lake of Asia) attracts tourism and the architecture of this place is unmatched in the whole world.

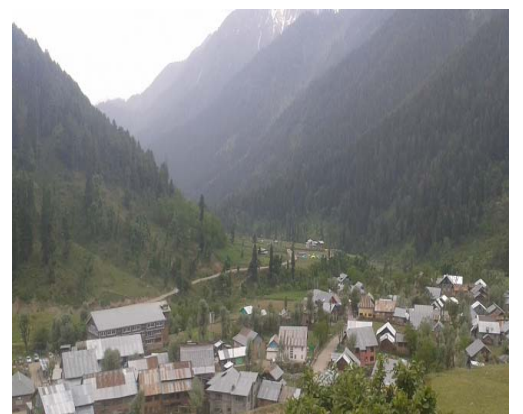

Fig. 7. Temporary colony \& view from Shikara, Srinagar; Source: author (2016)

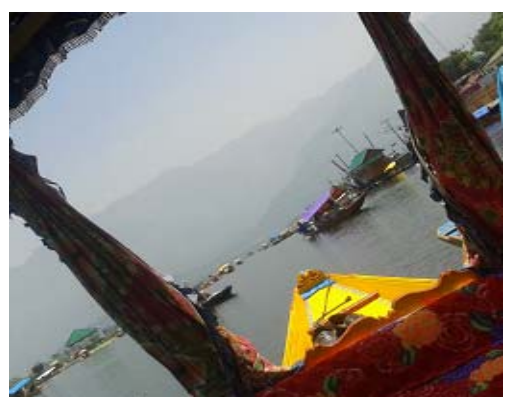

Fig. 8. Floating Architecture, Srinagar; Source: author (2016)

\section{6) England- The Moving Architecture}

The Walking City, a unique representation of architecture developed in England (1960s) proposed by British architect Ron Herron in avant-garde journal Archigram showcasing post-apocalyptic world, after a nuclear war. The Walking City became one of Archigram's best known images for city architecture. It had the concept of mobility wherein robotics technology will be used for developing ambulatory mega structures capable of walking on both land and sea. It had huge mechanized structures with intelligent minds and huge ship vessels on walking stilts. The city is a combination of insect and machinery and was a reflection of Le Corbusier's idea of a house as a machine. Few walking cities may interconnect with each other to form larger walking metropolises. Similarly, Walking houses were utilized for the people who couldn't live in one place for a long time based on mobility parameter. One of its' kind was Dymaxion house promoted by Architect Buckminster Fuller in 1920s. Dymaxion term was framed by combining Dynamism, Maximum and tension aimed to deliver transportable, affordable, and energy efficient structures which will provide mobile spaces. Since 1970, the title of "walking house" was replaced by prefabricated house as mobility became less important with the succession of need for space expansion. One of the main advantages of such houses is their application at the time of disasters as they could be installed quickly and will aid in providing comfortable habitable spaces to the users during critical hours as well. As discussed earlier, Loft cube is a precedent of similar style that could be easily and quickly set up on the roofs having plain area and be transported by helicopters. 


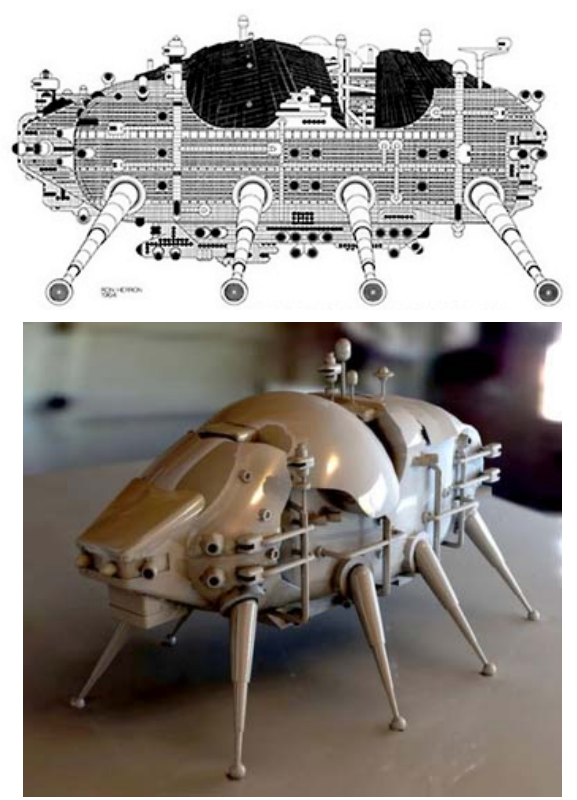

Fig. 9. Walking City model by Ron Herron

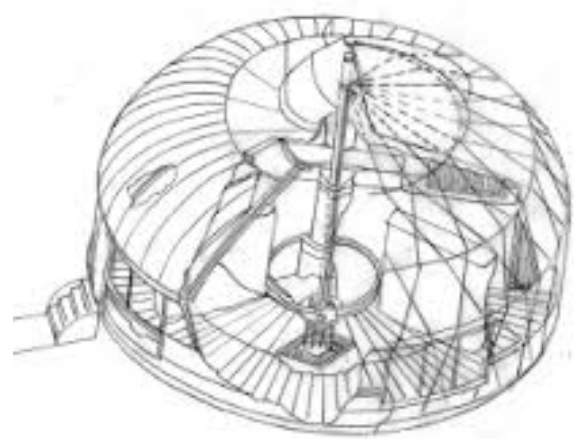

Fig. 10. Dymaxion house by Architect Buckminster Fuller

\section{7) Holland- World's floating country}

"God made the world but Dutch made Holland", As per IPCC report, rising sea levels caused by climate change are threatening coastal areas where in a small water level fluctuations will worsen the situation. Holland is a country with $20 \%$ of its area below the sea level which is mostly at risk from rising sea levels, flood waters; in addition it has been projected by the experts that in the coming 200 years the sea level will raise in the country by $4 \mathrm{~m}$. To battle this situation 'Living with water' concept is being accepted by the Holland populace who have now shifted their aim from working against water to work with water and devise methods that will help in creating comfortable, habitable and sustainable spaces required for human survival. Consequently, Holland is probably the first floating country, in which the notion of housing had transformed into amphibious homes. Further, keeping in mind the precedents of cities which have worked with water, floating structures have been included in country's urban planning. The archaistic housings of Amsterdam along the river is not uncommon scene with terraces or small gardens and this is the only solution to deal with housing shortages as the coastal areas are rich in dock lands which could be utilized to expiate this situation. Besides rise in sea level, Flexible architecture helps to deal with major problems of growing urbanization and planet's overpopulation. 

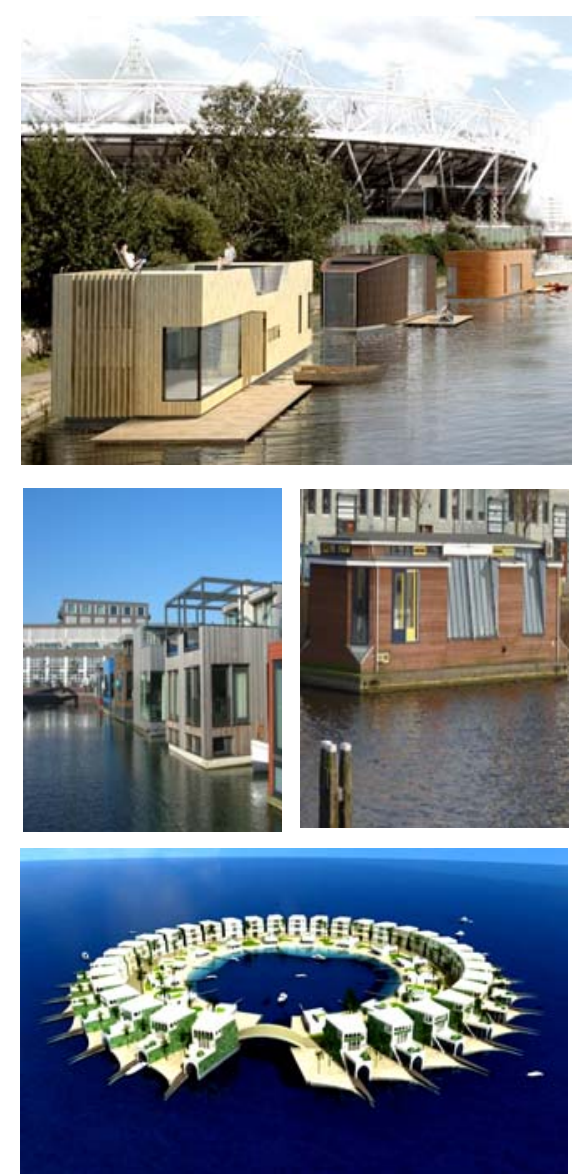

Fig. 11. Picturesque Floating houses, Amsterdam \& Netherland, Dutch Island model

\section{8) Kingdom of Saudi Arabia- Known for World'slargest tent structures}

Mecca is unarguably the most congested public space in the world accommodating three million Muslims for Hajj pilgrimage with densities often exceeding 6 people per square meter which demands comfortable and safe environment for both visiting and autochthonic multitudes. This dense concentration of people for short period calls for careful design to ensure safe and efficient pilgrim movements and economical stay. The deliberate way to overcome this floating large populace can be overcome by incorporating flexible architecture designs such as tent structures for accommodating believers. For accommodating pilgrims during Hajj duration, the tent structures were erected in Mina valley, near to Mecca (Hajj's midpoint) thereby promulgating it as the world's largest tent city. One lacsfire resistant 'fibre glass tents' occupying $20 \mathrm{~km} 2$ area replaced earlier cotton tents which were ruined during a deadly fire in 1997. The tents are designed as air conditioned spaces well equipped with kitchen, bathrooms, and ablution facilities. It is inflammable, configurable, wind resistant, non-toxic and protect from harsh heat gain by allowing only $10 \%$ of sunlight to penetrate. It is armoured with speakers, thermostats and fire alarms for creating comfortable and safe habitable spaces.

The design origin of German Architect Fre Otto and Mahmood Bodo Rosch in forms of ceiling of Prophet Mosque in Medina has got its inspiration from nature in context of opening-closing of a structure such as blooming of bud. The moving dome and canvas structures not only add beauty but also create a sense of openness and closeness. These structures opens up during the day to provide shadow to worshipers from blazing sun thereby creating pleasant and congenial environment which opened in the evening and adds beauty at twilight. Besides movable domes the mosque of Medina has twelve $17 \mathrm{~m} \mathrm{X} \mathrm{18m} \mathrm{stretchable} \mathrm{umbrellas} \mathrm{which}$ attain a height of $14 \mathrm{~m}$ in the open position which fits into the courts. The diagonal span of $24 \mathrm{~m}$ makes it largest of its kind ever built. The cone-shaped membrane creates the effect of a translucent vault spanning between the columns and arcades. The noble form, sharply designed surfaces, with the traditional stone architecture blends. This effect yet stronger when vertical sheathing of the closed umbrellas unfolds and the gathered membrane opens like a flower. What an Aesthetic. 

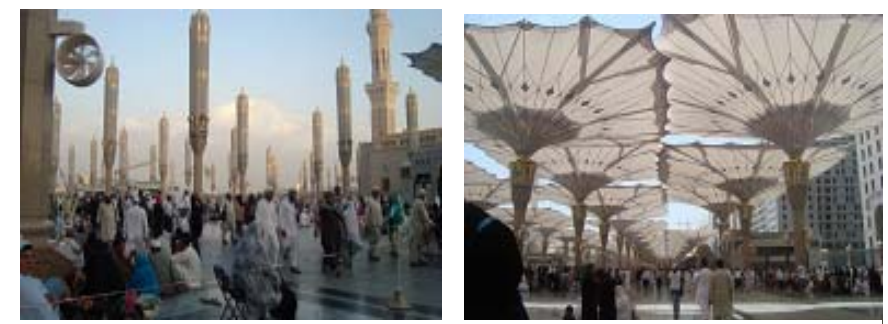

Fig. 12. The closed and opened umbrellas in Medina Mosque; Source: author (2015)
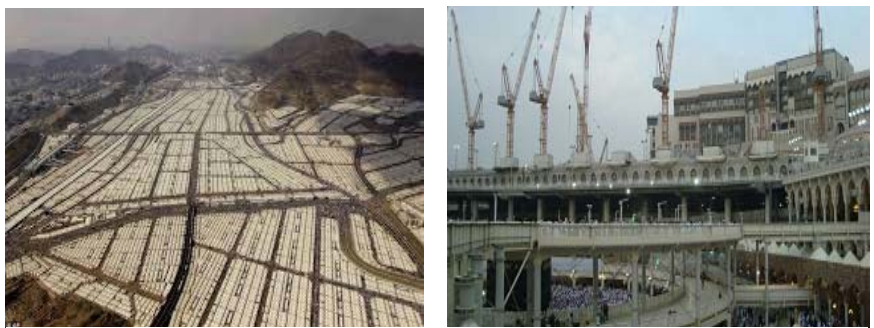

Fig. 13. Tent city of Mecca and Temporary Mataf structure, Mecca; Source: author (2015)

\section{9) China- Instant Architecture}

The aftermath of the Wenchuan earthquake in China persisted everyone to prepare for disaster emergency architecture worldwide. The exhibition invited 17 internationally renowned architects team to design feasible, efficient, safe, beautiful and user-friendly emergency shelters for the victims of such earthquakes, hurricanes and social epidemic diseases. The structures were characterized by economical production; ease of assembly transportation and for long time functionality.

Red+Housing was designed by OBRA Architects in May 2009 and was dedicated to the victims of Sichuan earthquake (May 2008). The area engulfed was as long as $400 \mathrm{~km}$. Nearly 90,000 people were reported dead or missing and 400,000 injured. The severity was such that it left 12 million people homeless. The project utilized local low-cost building materials like Bamboo plywood strips that ensure the structural strength. Covering fabric for the roof was made of waterproof bamboo fibres. Red colour was chosen to appear like Red Cross, which is internationally recognized sign for aid.

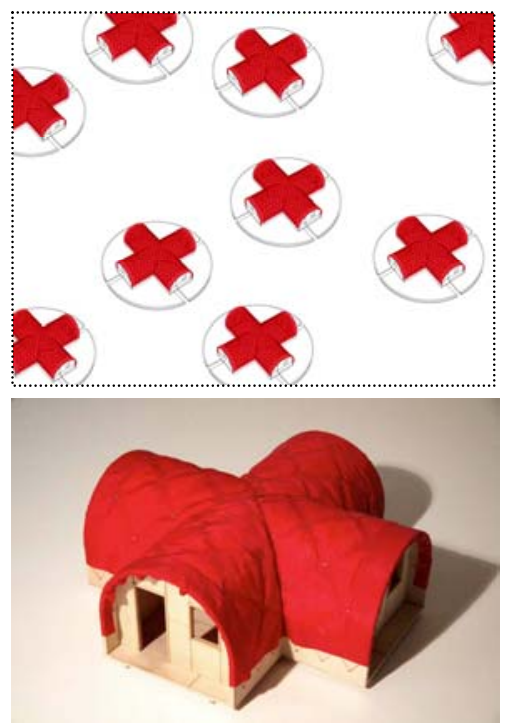

Fig. 14. Aerial and Front view of Redcross housing 


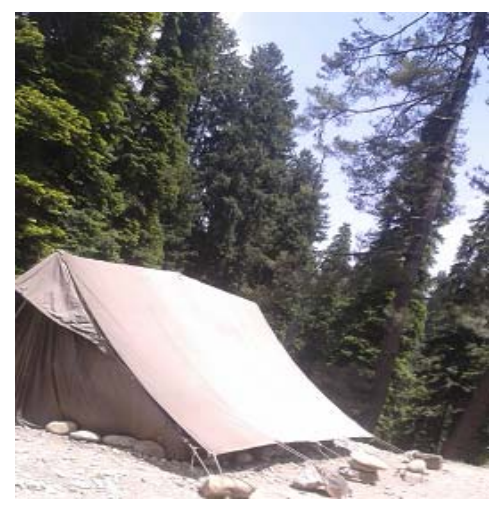

Fig. 15. Foldable Tents for Army

\section{0) USA- Adaptive Transformation in Architecture}

Adaptable and transformable structure is also recognized as an essential component in creating sustainable architecture and for the sustainability of environment. The transformation process and mechanisms used to enable movement have to be reliable, robust, and easily operable. New materials and new strategies should be employed to develop rational and flexible architecture which is capable of responding to climatic situations and adapt themselves accordingly without disturbing comfort and efficiency of a space. Container guest house designed by Poteet Architects is a sensitive adaptive design showcasing reuse of existing building material with innovation and corresponding interiors. The sustainable strategies are implemented such as climate responsiveness design, extensive use of recycled material- the container, foundation comprising of recycled telephone cable etc., composting toilets and usage of grey water for roof top irrigation etc.

Drop City known as the first American rural "hippie commune" was established in 1965 and abandoned in 1973. It was developed as a space inhabited by free-thinking people who had their own vision of a lifestyle, free from obligations-social, rules and regulations, etc. The desire was to experience an extraordinary style of living. The core idea of the Drop City, founded by Gene Bernofsky was to envision the development of a radical new civilization. In 1965, 7 acre plot near Trinidad, Colorado, was bought for creating a live-in space- a work of Drop Art. The Domes and remarkable structures were built without any working plans. Discarded junks were used as building materials, like cut-out roof tops hacked out with axes; scrap lumber, auto windshields etc. The Drop City design focused on reconnecting with nature and embracing harmony in simple living. Dwelling through utilization of minimum luxuries, embracing simplicity and freedom from society's rules, materialism and capitalism.
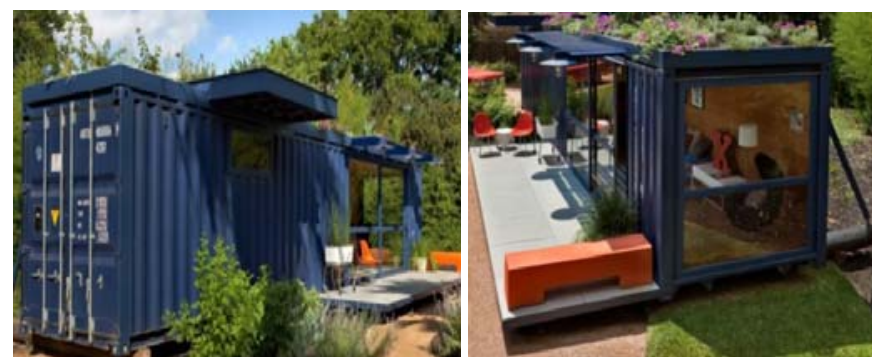

Fig. 16. Shipbing container guest house bv Poteet Architects. USA. 2010

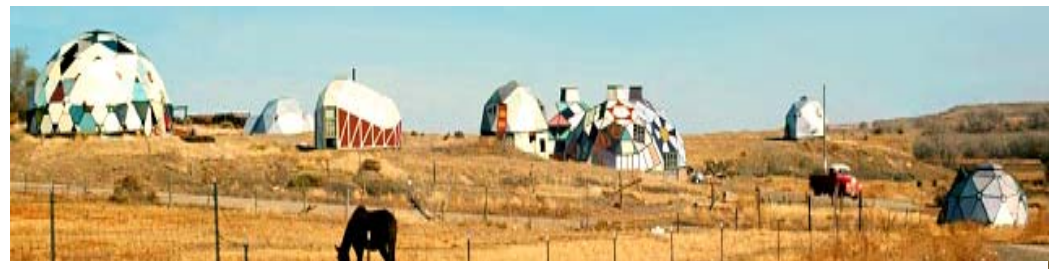

Fig. 17. Drop City founded by Gene Bernofsky 


\section{DISCUSSION}

The examples like Loft cube, Theater of Berlin, Red+ housing, Floating Houses, Dynamic Tower, artificial islands, tent city, expandable umbrellas, etc. are considered to show how unconventional architecture- Flexible Architecture, provides a solution to the existing societal, climatic and need based structures through economic utilization of materials and available resources.

Red+Housing as instant architecture showed a variety of tendencies and features focused on active and tangible responses to meet societal and environmental issues. The mobile, movable and transferable architecture emphasized on the economic use of materials, technologies and also keeping in consideration need of the society which justified the concepts of flexibility to create innovative architecture. Modern architecture progress is based on positive ideology. The new light weight and high strength materials such as plastic laminate, glass reinforced plastics etc. used for Loft cube and expandable structures has revolutionized architecture. The flexible architecture adapts, reflects, and restructures the way we perceive the possibilities of living. Flexible architecture meets social, cultural, political and environmental requirements. It guides architects for efficient utilization of resources and energy. The portable appliances, easy displacement, and multipurpose performance are achieved by Flexible architecture. Besides that, increased apartment demand, population growth, and economic issues, are easily met through adoption of flexible architecture.

From this manuscript, it is thus concluded that Flexible Architectures connects us with the environment as per the demand of new era. It is effectively movable, sustainable, and transformable and can cater multiple activities in one space with emphasis on economical use of space, energy and resources. Flexible Architecture is capable of meeting world challenges such as mitigating the adverse conditions of climate change, serving high density of population, and creating sustainable communities which will help in regaining the natural environment and air quality of our mother planet.

\section{ACKNOWLEDGMENT}

We thank the anonymous referees for their useful suggestions, critic and content; along with this, I would be thankful to various people and person met during visit and obviously the patient company. This would be incomplete, without the name of Department of Mechanical Engineering as well as Architecture and planning, Integral University, Lucknow, India.

\section{REFERENCES}

[1] Kisho Kurokawa, 2002, What is the Legacy of Modern Architecture?, quoted in Henket \& Heynen, , p 253

[2] Pilar Echavarria, 2005, Portable Architecture - and Unpredictable Surroundings, p 24

[3] Robert Kronenburg's lecture on flexible architecture at the Building Centre in London, 5 March 2011

[4] source: http://vimeo.com/21803296

[5] Aghil Emamgholi, 2011, Flexible space in Architecture, 5th symposium on advances in Science and Technology, SAS Tech, 12-17, accessed on $12 / 7 / 2016$

[6] Fact sheets, www.docstock.com, accessed on 16/06/2016

[7] Based on CNN; World's most expensive parking places, November 22, 2012, accessed on 29/07/2016

[8] http://flashydubai.com/8-wonders-of-dubai-amazing, accessed on 14/06/2016

[9] KASHMIR NEWS; Kashmir Changing Architecture.. Shrinagar, June, 08, 2014, accessed on 28/07/16

[10] Kronenburg's lecture on flexible architecture at the Building Centre in London, 5 March 2011, source: http://vimeo.com/21803296

[11] Le Corbusier, Towards a New Architecture, 1976, p.82, quoted in Heynen, 1999, p.14

[12] David Archer and Stefan Rahmstorf, 2010, The Climate Crisis - an introductory Guide to Climate Change, p.62 - 67

[13] Booz Allen Hamilton, 2013, Analytics driven master planning for Mecca: Increasing the capacity while maintaining the spiritual context of Hajj pilgrimage, Proceedings of Winter Simulation Conference, p. 241-252

[14] Khalid A. H. Taher, 2006, Form Finding and Value Engineering in the Design and Construction of the Mechanical Umbrellas for the Holy Mosque in Medina, Kingdom of Saudi Arabia, VALUE WORLD, volume 29, number 1, Summer 26.

[15] ARAB NEWS, With bridge dismantled Mataf capacity will rise, Published, 5 April 2016, accessed on 30/07/2016

[16] ARAB NEWS, Easing Mataf; Proposal floate to expand Mataf, Published, 17 June 2011, accessed on 30/07/2016

[17] Stephen Cairns, 2004, Drifting: Architecture and Migrancy, p. 23

\section{AUTHOR PROFILE}

Dr. Mohd. Anas, Associate Professor, Department of Mechanical Engineering, Integral University, Lucknow, India. Email address: anas@iul.ac.in

Safiullah, Associate Professor, Department of architecture and Planning, Integral University, Lucknow, India. Email address: safi@iul.ac.in

Zeba Nisar, Associate Professor, Department of architecture and Planning, Integral University, Lucknow, India. Email address: zeba@iul.ac.in 